Article

\title{
Sustainability and Ecological Civilization in the Age of Anthropocene: An Epistemological Analysis of the Psychosocial and "Culturalist" Interpretations of Global Environmental Risks
}

\author{
Jean-Yves Heurtebise ${ }^{1,2}$ \\ 1 Department of French, FuJen Catholic University, Taipei 24205, Taiwan; jy.heurtebise@gmail.com \\ 2 Centre d'Etudes Français sur la Chine Contemporaine (The French Centre for Research on Contemporary \\ China-CEFC), UMIFRE 18, MAEE-CNRS, Hong-Kong, China
}

Received: 20 April 2017; Accepted: 26 June 2017; Published: 1 August 2017

\begin{abstract}
The aim of this article is to assess the validity of the culturalist explanation of unsustainability by critically examining the social-cultural interpretation of the risks on which it is epistemologically based. First, we will explore the different ways in which the notion of Anthropocene is changing our perception of risks. Second, we will analyze the limits of the social-cultural explanation of risks relative to the global (non-linear) interdependence between human activities and environmental processes that defines the Anthropocene. Third, we will introduce the Chinese concept of Ecological Civilization and analyze its cultural foundations and culturalist assumptions. Finally, we will develop the practical consequences of this critic of the social-cultural interpretation of risks and of culturalist explanations of unsustainability.
\end{abstract}

Keywords: risks; Anthropocene; social construct; Planetary Risks; risk perception; environmental sociology; ecological civilization; Asian ethos; Culturalism

\section{Introduction: Anthropocene, Planetary Risks and the Limits of Culturalist Interpretations}

Our current mode of production and consumption of goods, in addition to our exploitation of organic resources, all modeled with regard to human economic productivity and not to bio-capacity, is endangering man's living environment, but all the while transforming human's social institutions: "The science is clear that a significant part of recent global warming is driven by human activities. [... ] [H] uman economic activity (energy and resource use, agriculture, forestry and more) leads to changes in Earth system elements (climate, land cover, sea level change and more) which are fed back into the distribution and kinds of human activities which are economic" [1]. Based on what we want and not on what we have, our way to achieve our ends goes beyond our means: "Human activity is putting such strain on the natural functions of Earth that the ability of the planet's ecosystems to sustain future generations can no longer be taken for granted" [2]. Global Risks emerged when the social part of the "social-ecological system" outweighs and overrides its ecological counterpart: "Global environmental risk refers to threat (to human being and what they value) resulting from human-induced environmental change, either systemic or cumulative, on the global scale" [3]. Risks in the age of the Anthropocene are the direct consequences of this ongoing process of global anthropization of nature (through industrial exploitation and technological exploration): "The most likely global catastrophic risks all seem to arise from human activities, especially industrial civilization and advanced technologies" [4].

The Anthropocene marks a new age in the relationships between human beings and their environment. During most of history, humans have been the prey of nature, in constant struggle of it. 
With domestication, urbanization, and industrialization, humans have succeeded not only in adapting to nature, but in adapting nature to man, (by satisfying their own social needs). However, recently, man realized they were the first casualty of their own Pyrrhic victory over nature: "conquered, the world is finally conquering us" as Michel Serres stated [5]. First a prey, then a predator, man ought to become a "creative protector": not only protecting nature from himself, but protecting himself from his own desire of exploitative domination [6].

The Anthropocene is not only a term stressing the totipotent influence of human beings on nature, but a geological category evidencing "the capability of contemporary human civilization to influence the environment at the scale of the Earth as a single, evolving planetary system" [7]. It denotes also an age in which all the boundaries between science and society, society and environment, artificial and natural, global and local collapse [8].

The Anthropocene age of Planetary Risks is a moment of global crisis and every moment of crisis is propitious both to soul-searching inquiry and to scapegoat oriented resentment. In this context, the concomitance of post-colonial studies and environmental awareness lead to the emergence of a new post-colonial eco-political claim: if it is true that our current environmental crisis started with European Industrial Revolution, should we not link this crisis to European culture as a whole? As a consequence, could we hypothesize that only non-European cultures, especially Asian cultures, can provide the ethical, philosophical, and even political foundations to resolve this global crisis? [9]. Thus emerged the concept of "Chinese Ecological Civilization" [10].

The aim of this article will be to assess the validity of this culturalist explanation of unsustainability by critically examining the social-cultural interpretation of risks on which it is epistemologically based. First, we will explore the different ways in which the notion of Anthropocene is changing our perception of risks. Second, we will analyze the limits of the social-cultural explanation of risks relative to the global (non-linear) interdependence between human activities and environmental processes that defines the Anthropocene. Third, we will introduce the Chinese concept of Ecological Civilization and analyze both its cultural foundations and culturalist assumptions. Finally, we will develop the practical consequences of this critic of the social-cultural interpretation of risks and of culturalist explanations of unsustainability.

\section{Risks in the Age of Anthropocene}

In 2000, the geochemist Paul J. Crutzen, 1995 Chemistry Nobel Prize recipient, expressed for the first time the idea that our planet entered — since the end of the eighteenth century-a new age where anthropic activities such as industrialization, mass-scale deforestation, global urbanization, overfishing, and consumption of fuel fossils produced a massive emission of greenhouse gas (carbon dioxide, methane, and nitrous oxide) and an accumulation of plastic waste in terrestrial soils that marked a new geologic period: the Anthropocene [11].

The notion of Anthropocene means that human beings have become the most important driving force shaping the geology of the Earth. A point of heated discussion concerns the origin of the Anthropocene [12]: when did it start? 8000 years ago with the first forest clearance by human groups in India, China, and Europe? 5000 years ago with the expansion of rice farming and increasing livestock numbers in Europe and China? 2000 years ago with the extensive agriculture farming of the Roman Empire and Han Empire? 200 years ago with the onset of the European Industrial Revolution? 50 years ago with the 'Great Acceleration' of the second half of the twentieth century [13,14]? In 2007, when for the first time more than half of the world's population lives in urban areas-creating a world-wide "urban strata" [15]?

An article published in 2015 in Nature "suggest [ed] that two of the various proposed dates do appear to conform to the criteria to mark the beginning of the Anthropocene: 1610 and 1964" [16]. Though the discussion about the inception of Anthropocene [17] and the formal or informal nature of the concept in terms of geological classification is not over [18], there is a global scientific consensus on the idea that "since the Industrial Revolution, a new era has arisen, the Anthropocene, in which 
human actions have become the main driver of global environmental change [ ... ] with consequences that are detrimental or even catastrophic for large parts of the world" [19]. According to Gaffney and Steffen: "in the last six decades, anthropogenic forces have driven exceptionally rapid rates of change in the Earth System"; the rate of change in climate driven by industrialized societies is 170 times faster than the rate of change driven by natural forces [20]. The detrimental consequences of the Anthropocene both for animal biodiversity ("sixth mass extinction") [21] and human public health are fully acknowledged. According to a 2014 report of the World Health Organization (WHO): "between 2030 and 2050, climate change is expected to cause approximately 250,000 additional deaths per year, from malnutrition, malaria, diarrhea, and heat stress. The direct damage cost to health [ ... ] is estimated to be between US\$2-4 billion/year by 2030" [22].

If we define risk as "a situation or an event where something of human value (including humans themselves) is at stake and where the outcome is uncertain" [23], then the Age of the Anthropocene is indeed the age of Global or Planetary Risks. "The most catastrophic changes in ecosystem services [ ... ] involved nonlinear or abrupt shifts. We lack the ability to predict thresholds for such changes, whether or not such a change may be reversible, and how individuals and societies will respond" [24]. Moreover, the fact that "anthropogenic activities affect not only some ecosystem components, e.g., fish stocks, but can be responsible for large-scale ecosystem perturbation could have profound implications for management" [25].

Climatic environmental risks involve potential non-linear abrupt changes with low probability, but high consequences that are often not taken into considerations by decision makers, who rely on prospective studies based on most likely outcomes: "most climate change assessments rarely consider low-probability, but high consequence extreme events [ . . . ] Thus, decision-makers reading the 'standard' literature will rarely appreciate the full range of possible outcomes, and thus might be more willing to risk adapting to prospective changes rather than attempting to avoid them" [26]. We plan to "mitigate" standard risks more than we try to avoid them-thus reinforcing the possibility for unpredictable extreme events to happen.

As Jean-Pierre Dupuy said, paradoxical as it seems, the belief that we will be able in the future to successfully address this global social-ecological crisis (with better education, better technology, deeper governmental involvement or stakeholders' participation, etc.) leads us to postpone acting on its resolution now and here. Only the belief in the severity of the present catastrophe can give us the impetus to actually prevent it: "Even when we see the catastrophe staring at us we do not believe what we know to be the case. In part this is because the willingness of a community to recognize the existence of a risk depends on the degree to which it is convinced that solutions exist" [27]. Non-linear interactions between human activities and ecological processes leading to global Planetary Risks demonstrates that our capacity to change the world has outpaced our capacity to control the social-environmental consequences of these changes: "our capacity to act upon the world in such an intensive and extensive way that the consequences of our actions have escaped our capacity to foresee them" [28].

Accordingly that the notion of Anthropocene bears important consequences for the concept of Sustainability. According to the classic 1987 definition: "Sustainable development is development that meets the needs of the present without compromising the ability of future generations to meet their own needs" [29]. But if the Anthropocene started in 1610 and even more in 1964, then it is clear that there is an irreversible generational gap between pre-Anthropocene humanity and us. Moreover, since the notion of Anthropocene is an acknowledgment of the fact that the ecology of the Earth has been completely transformed by human activities, i.e., since the current "human footprint" already exceeds Earth's capacity both to generate resources and absorb waste, then the ultimate criteria for sustainability is less the capacity of next generations to satisfy their own needs in the future (since the nature of these needs, the state of technology and the situation of the Earth cannot be forecasted with enough precision) than man's capacity to regulate his present needs according to current available resources [30]: "Transition to sustainability requires reducing human consumption to be within 
ecological limits" [31]; "social-ecological sustainability requires that society's economy and other human activities do not exceed the capacity of ecosystems to provide services, which is constrained by the planet's life-support system in return" ([32], p. 6).

\section{The Cultural Interpretation of Risks and Its Limits}

An earthquake occurring in the depths of the Pacific Ocean is a natural event that may be of interest for the geologist; it does not constitute a risk as long as it it does not constitute a threat for human society. The definition proposed by Ortwin Renn emphasizes the anthropic-based nature of risk: "risk is an uncertain consequence of an event or an activity with respect to something that human beings value" [33]. There are many kinds of risks: terrorist risk, technological risk, environmental risk, etc. but risk always means the irruption of a potential threat to the "stability" of human society, something disrupting the social "order".

Maybe because risks are endangering a state of things we value, we have a tendency to think that risks themselves are an analytic projection of the collective psyche. The social-cultural interpretations of risks start with the notion that, as stated by Paul Slovic, "risk does not exist 'out there', independent of our minds and cultures, waiting to be measured" [34]. According to Sheila Jasanoff, it is to the credit of social sciences that risks "from something real and physical if hard to measure, and accessible only to experts" came to be seen as "something constructed out of history and experience by experts and laypeople alike" [35].

In many ways, Ulrich Beck's and Mary Douglas' works, which decisively contribute to the contemporary definition of Risk, are not exempt from this social-constructivist conception of risks that they also contribute to establish.

Ulrich Beck's concept of Risk Society (Risikogesellschaft) stems from a historical reflection on modernity: "Modernity, which brings uncertainty to every niche of existence, finds it counter-principle in a social compact against industrially produced hazards and damages, stitched together out of public and private insurance agreements" [36]. During the period of the first modernity, industrial risks were covered by the State and private companies as a collective compensation for workers' labor. However, with scientific-technological progress giving man a capacity of action that exceeds their capacity of prediction and control, global social-environmental risks emerged: "In their brilliant perfection, nuclear power plants have suspended the principle of insurance not only in the economic but in the medical, psychological, cultural, and religious sense. The residual risk society has become an uninsured society, with protection paradoxically diminishing as the danger grows" [36]. Ulrich Beck's concept of Risk Society has been criticized by tenants of the social-cultural interpretation for being too realist and objectivist [37]. This criticism is both untrue and misplaced. It is untrue because Beck did insist on the representational nature of risks in post-modern societies: "The world has not grown unconditionally more risky. Rather it is the systemic lack of trust that makes consumers so quick to see risks everywhere. The less trust, the more risk" [38]. Additionally, the notion is misplaced because because it is Beck's attention to the technological aspect of risks production that represents its most valuable contribution to risk theory.

Mary Douglas' understanding of risks does embrace social-cultural constructivism: "There could be no risks, illnesses, dangers, or any reality, knowledge of which is not construed. It might be better if the word 'social construal' was used instead of 'construction', because all evidence has to be construed" [39]. To illustrate this point, Mary Douglas, in Purity and Danger, draws a parallel between taboo and pollution as social-moral constructs: "pollution is a type of danger which is not likely to occur except where the lines of structure, cosmic or social, are clearly defined" [40]. (Let us note that Beck also equated pollutants and toxins to medieval devils arousing an "irrational" sentiment of fear [41]). For Douglas, both taboo and pollution manifest the disruption of the social-cultural order, conveying notions of fault and abnormality: the difference being that taboo concerns the community as a whole, while risk concerns the individual [42]. The aversion to risk is thus nothing but the manifestation of the individualism of modern societies and of its pathological need for a sense of 
security impossible to satisfy: "Risk is [ . . ] immeasurable and its unacceptability is unlimited [ ... ] There can never be sufficient holiness and safety" ([43], p. 184). This "irrational" aversion to risk is viewed by Douglas as a strategic tool used by the "sectarian groups", viewing "nature in the old primitive way", to make a political claim: "impurities in the physical world or chemical carcinogens in the body are directly traced to immoral forms of economic and political power" ([43], p. 47).

However, defining risks as social-cultural constructs is in many ways, epistemologically inaccurate, sociologically partial, and ecologically inconsistent.

First, in his 1921 essay, Frank H. Knight noted that it is necessary to make a distinction between risk measured by objective probability and uncertainties assessed by subjective probability [44]. Risk refers to the probability of the occurrence of the (hazardous) event (objective or frequency probability), while uncertainty refers to the quantity of knowledge we have access to for supporting our belief in its happening (subjective or Bayesian probability). Moreover, as Terje Aven pointed out our common epistemological mistake is to confuse "risk assessments and risk perception": while "risk perception is based on personal beliefs, affects and experiences irrespective of their validity", "risk assessments are representations of individual and collective uncertainty assessments based on available statistical data" [45]. Thus it is not so much risks than uncertainties that are social constructs [46]. Uncertainty can be invoked by scientists to ask for more public funding to further investigate irresolute cases; but it can also be used by lobbyists to discard preventive policies in the name of ignorance or by lawyers to postpone the legal resolution of trials by asking the plaintiffs to provide complementary information in the name of incomplete data [47]. If uncertainties are often linked to psycho-sociological biases, risks analysis often goes with socio-economic struggle about safety policies between actors with conflicting interests [48].

Second, every society culturally does have different ways to prioritize risks according to their own preferences and needs. Bruno Latour remarked that potential risks of prions in the mad cow disease aroused more public concerns than actual traffic-related causalities ([49], p. 124). Similarly, Helmut Jungermann and Paul Slovic noticed that "hard" drugs kill 2500 people every year while nicotine alone kills about 100,000, equivalent to one jumbo jet crash every day; “yet, these 365 'jumbo crashes' arouse no public interest at all, even though they entail not only much personal suffering but also considerable societal cost" [50]. That risks perception is a social-cultural construct is not debatable. However what is debatable is Jungermann and Slovic's conclusion that "risk, it seems, is all in the mind-a construct" [50]. That the degree of importance we assign to risks is filtered by cognitive bias (depending on the cultural background, social status, or exposition to media of the social subject) does not mean that their degree of reality depends on mind habits. When Jungermann and Slovic concludes from public disinterest to nicotine-induced deaths that risks is a mind construct, he forgets that this so-called "disinterest" is a social fact construed by political-economic factors, notably tobacco industry intense lobbying: "The tactics used by the tobacco industry to resist government regulation of its products include conducting public relations campaigns, buying scientific and other expertise to create controversy about established facts, funding political parties, hiring lobbyists to influence policy, using front groups and allied industries to oppose tobacco control measures, pre-empting strong legislation by pressing for the adoption of voluntary codes or weaker laws ... " [51].

When Douglas contended that ecological risks are interpreted by environmental activists to put the (moral) blame on "capitalists", she seemed to forget two things: first, pollution is affecting not only human beings, but the environment as well-and we cannot pretend it is due to a bias in animal or vegetal psychology; second, the lobbying of some industrial groups does have detrimental impacts on the legislation of environmental laws [52,53].

The regulation of sewage sludge in the United-States, analyzed by Horst Rakel, can also evidence this point. The first set of rules issued by the US Environmental Protection Agency "sent shock waves through the industry and upset many experts outside the EPA" [54] (as stated by Rufus Chaney, "taxpayers need regulations for sludge utilization based on proper research findings so that the minimum cost associated with environmental protection can be obtained" [55]). As a result, in the 
second EPA rule for sewage sludge, "apart from the complete omission of organic pollutants, the limit values for inorganic pollutants have become considerably less stringent" [54]. A comparison between US and EU sewage sludge land application limits confirms the low standard of the second set of EPA rules: the US ceiling concentrations for copper and zinc are two thousand times higher than the European ones. To explain this difference, the author first invokes the national "cultural bias" of the two "expert communities": the North-American one being more objective and science-based while the European one being more pragmatic and policy-based. However, at the end of the paper, she rightly points out that "separating environmental regulation into 'science-based' and 'policy-based' approaches appears to be more driven by political rhetoric, than by a profound appreciation of the issue at hand" [54]. The cultural explanation based on distinct "national psyche" overlooks the social-economic factors of risks regulations. It would be unconvincing to argue that the difference between US and EU concentrations limits of pollutants in sewage sludge is simply due to different levels of "public acceptance". There is no reason to believe that American citizens care less about safety than European ones. Some American citizens could be reticent to stricter regulations if it implies more control of state-level agencies and higher taxes, but more than "national culture", it is a matter of domestically divided political preferences.

Socio-cultural constructivism frequently overlooks the economic basis of power relations among social actors. "Public acceptance" and "risk-perception" are not based on group-psychology only: distinct class-difference and opposite economic interests can rationally lead to different kind of arbitrage: "The difference between state regulators/power companies who may seek to develop e.g., nuclear waste and related waste storage, and average citizens who may invoke precaution, may not be simply 'cultural' in the sense Douglas suggests. It may instead reflect fundamental differences in where each group sits in a complex political economy" ([56], p. 91). Risks are not simply a mind-construct but an irreducible by-product of an economic mode of production where human and environmental safety comes with an "additional" and "external" cost: "History has shown that the manufacturers and producers of products that pose these kinds of risks are unlikely to provide full information about these without some consumer or government coercion; after all, it is simply against their commercial interest to do so" ([56], p. 93).

If social-ecological risks can be said to be by-products of an unsustainable mode of wealth production ("wealth production within a 'risk society' typically depends on production technologies that expose citizens to dangerous substances" [57]), it is because the inequality of the distribution of economic capital ("just 62 individuals had the same wealth as 3.6 billion people-the bottom half of humanity" [58]) is related to the inequality in the consumption of natural capital: as demonstrated by Assadourian, the richest $7 \%$ of the population are responsible for $50 \%$ of $\mathrm{CO}_{2}$ emissions while the poorest $50 \%$ are responsible for $6 \%$ of them [59]. Furthermore, since the exploitation of resources benefits the most those who are more in the capacity to avoid its direct adverse consequences while, reversely, "the worst human effects of ecological plunder and degradation are often imposed on the poorest, most socially marginalized sections of the working class" [60], then environmental risks are closely related to the social-economic relations that frame our perceptions.

Third, global environmental risks, understood as social-technological by-products, cannot be addressed without amending the social-economic structure of our unsustainable mode of development [61]. Moreover, if it is true that Global Climate Change and Anthropocene are historically and logically linked, then risks are not simply the social-cultural mind-construct of a risk society (i.e., an anthropocentric concept), not only the political-economic by-product of an unsustainable mode of development but also the relational input of a "geo-anthropological system" (i.e., an anthropic reality that the term Anthropocene aptly captures-the Anthropocene being the reaction of natural systems to anthropic influences): the cycles of nitrogenous, carbon, and oxygen, the flows of oceanic currents and atmospheric flux, react both linearly and non-linearly, predictably and unpredictably, with human living habits. It is obvious then that the conventional definitions of risks need to be modified: when human beings are not only the victims of the hazards they try to prevent and manage but also the 
main contributors of their emergence, the distinction between subjective and objective risks becomes fuzzier. In the age of "post-normal science" [62] and STS studies [63], science is no more simply an explanatory form providing deterministic predictions but a transformative force with unpredictable outputs: "scientific and technological practices are among the main world uncertainty producers, introducing novel and emergent technologies, organisms and forms of life" [64]. The Anthropocene marks the inception of a new configuration of the geo-anthropological system in which interactions between science and society, natural forces and human activities become more intricate, non-linear and irreversible.

\section{Case-Study: The Constitution of the Concept of Ecological Civilization in China}

In order to give an illustration of the application of the socio-psychological interpretation of risks, we will provide a critical analysis of a special case of "culturalist" interpretation of environmental problems: the Chinese concept of "ecological civilization" $[65,66]$. By culturalist interpretation we mean a political revamping of some cultural sources that goes often with a reification and nationalist interpretation of a specific cultural tradition. Indeed, "Chinese culture" is as rich, as old, as complex, as multiform and heterogeneous both in space and time than the European one and thus any attempt to reduce it to some essential characteristics could be misleading.

The concept of "ecological civilization" was first promoted by Hu Jintao during the 17th National Congress of the Chinese Communist Party in 2007. It becomes an integral part of the 2011, 12th Five Years Plan and in 2013, during the third plenary session of the 18th Party Congress, it was included as one of the five national objectives (socialist economical construction, political construction, cultural construction, social construction, and ecological civilization construction). In 2014, the constitution of a Small Leading Group (SLG) [67,68] dedicated to Ecological Civilization (經濟體制和生態文明體制改革 專項小組) was created inside the bigger central SLG initiated by Xi Jinping in 2013 for the deepening of social-political reforms (中央全面深化改革領導小組). Since 2007, more than 4000 articles and books containing the key-word 'ecological civilization' have been published and more than 170,000 articles published in mainstream press-media evoked the concept in China.

In 2006, Pan Yue, then deputy director of China's State Environmental Protection Administration (SEPA), introduced the concept for the first time to cope with the environmental degradation caused by economic development: "In 20 years, China has achieved economic results that took a century to attain in the west. But we have also concentrated a century's worth of environmental issues into those 20 years. While becoming the world leader in GDP growth and foreign investment, we have also become the world's number one consumer of coal, oil and steel-and the largest producer of $\mathrm{CO}_{2}$ and chemical oxygen demand (COD) emissions" [69]. According to Pan, environmental problems in China are due to the adoption of the foreign model of Western development: "We live with Chinese culture, but our modernization drive is based on Western logic. However, it's not a wise choice to copy the Western model of industrial modernization, especially in China, because that model will result in serious conflicts with the environment and resources in such a developing country as China" [70]. As a consequence, since environmental threats come from the Western model of development, in order to reduce the exposition of Chinese society to environmental risks, it will be necessary to limit Western cultural influence and promote Chinese cultural tradition: "it's necessary to turn to the traditional Chinese culture for a correct guideline in our modernization and our cultural structure, as well as to make the ecological wisdom in the Chinese civilization an important component of the ecological civilization" [70].

The notion that there is an important ecological component in Chinese civilization is quite a recent idea in China: it has been notably advocated by Tu Weiming in an article about New Confucianism and Ecology: "New Confucians [ ... ] ecological turn has great significance for China's spiritual self-definition, for it urges the nation to rediscover its soul. It also has profound implications for the sustainable future of the global community" [71]. To support his claim, Tu refers to the Neo-Confucian philosopher Wang Yangming (1472-1529) professing the cosmological unity of men, animals and 
plants (and all things) [72]: "The great man regards Heaven and Earth and the myriad things as one body. He regards the world as one family and the country as one person" [73]. An editorial published in March 2015 by the People's Daily merged Pan Yue's concept with Tu Weiming's claim to contend that actual PRC environmental policies are rooted in a traditional concern for nature that is specific to Chinese culture: the "Taoist" notion that "men and nature are one" and that men "must coexist peacefully with Nature, and not try to dominate" is "one of the most essential components of Chinese tradition and China's most important contributions to humanity" [74].

Before discussing the content of the argument, it is necessary to provide its background context. The concept of "ecological civilization" was introduced in 2007 when China becomes the first global emitter of $\mathrm{CO}_{2}$ in the world. It was promoted during the same governmental meeting, i.e., 17th National Congress of PCC, than the concept of soft power [75]. The three mottoes of "harmonious society" (hexie shehui 和谐社会), “peaceful rise/development" (heping jueqi/fazhan 和平崛起/ 發展) and “ecological civilization" (shengtai wenming 生態文明) constitute the three faces of Chinese soft-power initiative that was built up after the Chinese translation of Joseph Nye's Bound to Lead [76] in 1992 by He Xiaodong and Ge Yuyun [77]. However, as noted by Joseph Nye himself, despite an investment in "soft-power" of about 8 billion dollars per year since 2006, despite the 2008 Beijing Olympics, the 2010 Shanghai Expo, and the creation of several hundred Confucius Institutes around the world "China has had a limited return on its investment" [78]. As Ian Hall and Frank Smith said: "despite, this increased investment in public diplomacy, however, a growing body of poll data and other evidence suggests that it has had little or no positive effect on foreign public opinion to date" [79]. One of the main reasons to explain this fact may be that, as many scholars have pointed out $[80,81]$, these slogans target the domestic public in the first place and aim at raising feelings of national cohesion and cultural pride while the objective of soft power is normally to convince others [82]: designed as defensive tools against "foreign criticism", these slogans failed to completely persuade foreign civil society.

Referencing back to the concept of Chinese ecological civilization, we can note that when Pan Yue affirmed: "it's not a wise choice to copy the Western model of industrial modernization, especially in China, because that model will result in serious conflicts with the environment" [70], he seemed to suggest that it is the Western quality of development, its so-called "cultural specificity" that will lead to growing environmental risks.

Such an idea is based on the culturalist narrative according to which "the essence of the Asian ethos is said to be 'a holistic harmony' in contrast to the European inclination to dualistic individualism" [83] and "traditional Chinese culture stresses the unity and harmony of nature and man" [84]. For Lu Shuyuan, the edification of an "ecological spirituality" (shengtai jingshen 生态精神) is necessary for Chinese to re-appropriate everything that was lost during the process of modernization (and westernization) in China [85]. Such a claim is not only shared by Chinese scholars, but also by Western ones such as Scott Slovic, an important scholar of eco-critic studies [86]: "What is unique in China are the core elements of environmental reverence that were articulated many centuries ago by Chinese philosophers and poets and are remembered even today in the twenty-first century. Today, when we speak about the emergence of an ecological civilization in China, we are, in a certain sense, referring to a re-assertion of traditional Chinese values rather than the creation of entirely new concepts, vocabularies, or attitudes" [87].

It is however necessary to qualify these "eco-culturalist" claims for different reasons.

First, it should be reminded that as Robert P. Weller, Professor of Anthropology and Research Associate at the Institute on Culture, Religion and World Affairs at Boston University, said: “'Nature' and 'environment' entered the Chinese vocabulary in their modern forms only early in the twentieth century ..." " [88]. This is not to say that it is impossible to find in Chinese classical texts, especially in Daoism and in Neo-Confucianism, many elements of thought that can positively contribute today to enrich our understanding of the man-nature relationship. On the contrary, one can find in Chinese and Indian cultural traditions many religious, literary and philosophical texts that could help to 
establish the cosmopolitical environmental ethics we need. Quoting Zhuangzi may illustrate this point: "The people have their constant inborn nature. They are one in it and not partisan, and it is called the Emancipation of Heaven (命曰天放—-mìng yue tiān fàng) [ . . . ] In this age of Perfect Virtue men live the same as birds and beasts, group themselves side by side with the ten thousand things" ([89], p. 66). However, the shift from an actual cultural tradition to a problematic culturalist interpretation occurs when original sources are framed by anachronistic, antagonizing ("Asian uniqueness"), and nationalistic (diplomatic soft-power, domestic propaganda) interpretations.

Thus, we must be aware that giving to Zhuangzi's ideal description of human life an environmentalist interpretation is perhaps anachronistic: Zhuangzi aimed less to condemn technological progress than to criticize Confucian moralists who wanted to refine human mores (manners) through the observance of numerous rituals. For Zhuangzi, morality comes out spontaneously as far as human nature is closely tied to 天/Tian-a polysemic word meaning Heaven, Sky, Nature, Destiny, etc. In the above mentioned 2015 People's Daily article, to anchor the principle of Ecological Civilization in Chinese classical texts, it is said: "2000 years ago, Zhuangzi issued the statement "Tian' and Men are One", meaning, at its core, that we should live in harmony with nature” (2000多年前庄子首次提出“天人合一”思想, 其核心是倡導人與大自然和平共處一2000 duō niánqián Zhuāngzǐ shǒucì tíchū tiānrénhéyī sīxiăng, qí héxīn shì chàngdǎo rén yú dàzìrán hépínggòngchǔ) [74]. But the sentence “天人合一” (tiānrénhéyī) does not appear in Zhuangzi; moreover, giving an environmentalist meaning to "天" / Tian" may be an over-interpretation. The meaning of 天人合一 (tiānrénhéyī) is not really to live in harmony with "Nature" as we understand it today, i.e., meaning the Earth, but to follow the "law" of the "Universe", the "Dao" that allows us "to ride the clouds and mist, straddle moon and sun" ([89], p. 15). Anachronistic interpretations can create an erroneous feeling of continuity that often contradicts with actual classic texts' meaning and past contexts. What we call "environment" in the age of Anthropocene and what traditional poets, philosophers or saints call "nature" in classical times is not one and the same: what moderns call environment is something that should be isolated from human influence (to study it scientifically) but can no more be insulated from it (due to industrially induced bio-chemical alterations); what traditional thinkers called "nature" was never purely "natural" but always haunted by non-human forces and ruled by unnatural entities. Our scientific mode of rational separation, our romantic sense of nostalgic loss, our environmentalist concern for irreversible contamination were not really included in the traditional "pre-modern" conception of nature.

Second, even if it was true that classical Chinese texts could have an environmentalist meaning, the reverse assumption, that such texts cannot be found in the Western tradition, is erroneous. To demonstrate the claim that the holist conception of man/nature interactions is uniquely Asian is not true, one may quote the Stoic philosopher and Roman emperor Marcus Aurelius' Meditations $(X, \S 6)$ : "let this first be established, that I am a part of the whole which is governed by nature". One could also refer to Western Renaissance's conception of macrocosm (universe) and microcosm (body) indivisible relationships or to the romantic conception of "Soul of the World" developed by Schelling [90]. One could even remind that the Greek, Roman and medieval medical conception of the body was based on a doctrine of four humors (linked to four elements themselves linked to four seasons) that shares many similarities with the medical and cosmological Chinese theory of five elements (五行). Thus, in a nutshell, equating Western culture with a mechanistic perception of nature is completely mistaken: this kind of conception of body and nature starts only to become predominant (but not exclusive) with the development of seventh century experimental physics and the Cartesian or Newtonian conception of the world [91].

In the West, the idea of an anti-ecological nature of Western thinking mostly comes from Lynn White's 1967 paper "The Historical Roots of Our Ecologic Crisis" contending that our current ecological crisis is due to the influence of Christianity on European modes of living: "modern technology is at least partly to be explained as an Occidental, voluntarist realization of the Christian dogma of man's transcendence of, and rightful mastery over, nature" [92]. The notions that God is above Nature, that 
Nature is not divine, that God has created the world and the animals populating it for the sole purpose of serving human needs and use are, according to White, the cultural roots of the European's will to exploit "Nature" in an unsustainable fashion. Needless to say that this thesis has been widely discussed [93] and often harshly criticized, notably by James Nash who contended that such a claim tends "to reduce the explanation of the complex ecological crisis to a single cause, [ ... ] to minimize the fact that non-Christian cultures also have been environmental despoilers, [and] to overlook the number of dissenting opinions in Christian history" ([94], p. 74). The weakest point of White's argument lies in the historical fact that the development of the Industrial Revolution coincided with the gradual secularization of Europe; thus it can be also argued that it is not the influence of Christian ideas but their gradual disappearance that made unsustainable industrial capitalism possible. Indeed, as Marx and Engels pointed out, by inducing the decomposition of all social ties except selfish greed, industrial capitalism led to a massive process of "deculturation" paving the way to the unsustainable exploitation of nature: "The bourgeoisie has put an end to all feudal, patriarchal, idyllic relations [ ... ] and has left remaining no other nexus between man and man than naked self-interest [ ... ]. The bourgeoisie has created more colossal productive forces than have all preceding generations together. Subjection of Nature's forces to man, [ ... ] clearing of whole continents for cultivation, canalization of rivers, whole populations conjured out of the ground" [95].

Third, even if it were true that classic Chinese texts anticipated contemporary environmentalism and that such an awareness of the importance of man/nature interactions were absent from the European tradition and that is the reason why unsustainable development occurred in modern times, the notion of a specifically Chinese Ecological Civilization does not fit with historical records of past environmental governance in China. Not only massive deforestation caused by extensive rice cultivation was already a concern in imperial China [96], but during the Maoist period, the Great Leap Forward promoted man's conquest of nature (人定勝天—réndìngshèngtiān) and engaged in deforestation to support agriculture (开荒种粮食—kāihuāng zhòng liángshi) [97]. It should also be mentioned that, until recently, Asian leaders considered environmental regulations as means used by "Western powers" to limit their development: "to many Asian leaders, Western concern for areas such as human rights and the environment is often seen as unwarranted interference at best and as revealing ulterior motives at worst" [98]. Even after the concept of Ecological Civilization has been officially adopted in 2007, the release of air pollution measures for Beijing by the American Embassy in 2008 attracted severe criticism: as late as 12 October 2011, the Global Times gave voice to a doctor at Peking University People's Hospital saying: "the suggestion to wear masks will make trouble out of nothing ... " [99]. Here political issues of (national) sovereignty interfere with (international) environmental duties.

This is the main problem with the culturalist interpretation of environmental threats: used as a strategic tool to support national sovereignty in the name of cultural specificity, it contradicts with the eco-cosmopolitan requirements of environmental ethics today [100]. Thus, it could become an obstacle to the international resolution of environmental issues: "environmental dangers pose supranational problems; these need solutions to which national governments are not well suited" [101]. Only cosmopolitan environmental ethics, to which every culture can equally contribute, can cope with the global nature of risks in the Anthropocene [102]. Delanty and Mota emphasize rightly the ethical and political implications of the Anthropocene understood as a "Cosmoplocene" [103].

Finally, as Zhang Wei rightly noted, the Chinese concept of ecological civilization comes from the works of American ecologists, from Aldo Leopold to Roy Morrison [104]. The first explicit use of the term ecological civilization comes from Roy Morrison's book Ecological democracy in which he contends: "an ecological civilization is built on three independent pillars: democracy, balance and harmony" [105]. What is the best mode of political governance for preventing and mitigating global environmental risks? Differing from Ophuls who affirmed in 1977 that "the only solution is a sufficient measure of coercion" [106], Morrison stressed the fact that "democracy" (meaning not so much the political 
capacity to vote for people's representatives than the social capacity to freely express innovative ideas and vital concerns) is an essential component of any sound and fair "ecological civilization".

Indeed civil liberties are not simply a political right but are today understood as an essential component of comprehensive environmental rights [107]. Many scholars in the past have mistakenly opposed Western ("individualist") human rights with Asian ("collectivist") subsistence rights [108]: "First of all, many countries in Asia and South East Asia [ ... ] are concerned with overcoming starvation and poverty, not by means of promoting human rights, but by increasing national wealth and mutual aid" [109]. However, since the 1950 preamble of the Universal Declaration of Human Rights stating that "human beings shall enjoy freedom of speech and belief and freedom from fear and want" and the article 1 (2) of the 1966 International Covenant on Economic, Social and Cultural Rights (ICESCR) stating that "under no circumstances may a person be deprived of its own means of subsistence" [110], the domain of application of human rights embraces not only political freedom but also subsistence rights. Secondly, subsistence rights are not only quantitative but also qualitative; as demonstrated by Henry Shue, subsistence rights are conditioned by the enforcement of ecological regulations: there is no right to water if it is polluted; there is no right to food if it is contaminated; and no right to shelter in a degraded environment [111]. In this sense, subsistence rights should be understood as ecological rights, i.e., rights to live in an environment where human-generated ecological risks are minimized-as stated in the 1972 Stockholm Declaration: "[m]an has the fundamental right to freedom, equality and adequate conditions of life, in an environment of a quality that permits a life of dignity and well-being" [112]. Thirdly, if it is true that human rights today include economic rights, it is also true that without political rights economic rights cannot be fully enjoyed: as enounced in the Aarhus convention, "the right of every person of present and future generations to live in an environment adequate to his or her health and well-being" supposes that "the rights of access to information, public participation in decision-making, and access to justice in environmental matters" is granted to everyone [113].

The notion of "Chinese ecological civilization" can be an internal political tool promoted to give a moral legitimacy to the enforcement of environmental regulations that could have adverse effects for domestic economy. In this respect, it is a useful and valuable ideology. However, when the claim, which the "Asian ethos is closer to nature" is used by developmental States to prioritize growth over rights in the name of national sovereignty, is justified by a more or less mythical (partially re-invented) "cultural specificity", it often leads to poor environmental performance.

\section{Conclusions: Risks as an "Anthropocenic" Reality}

Global environmental risks are an intrinsic part of the Anthropocene. The notion of Anthropocene has been coined to stress that "humankind [ ... ] has become so large and active that it now rivals some of the great forces of Nature in its impact on the functioning of the Earth system" [7]. Philippe Descola [114] and Bruno Latour ([49], p. 43) reminded us that the so-called dichotomy between men and animals, and between culture and nature was not a relevant paradigm in primitive people's mindset. It is only with the Scientific Revolution that nature and culture start to be separated [115]: nature was then equated to the universality of objective physical laws and culture equated to the relativity of subjective human customs ([49], p. 48). However, in the Anthropocene, Planetary Risks denote precisely that the distinction between a social and a natural domain of reality is obsolete: "We must understand the world, region, or community as a social-ecological system in which people depend on resources and services provided by ecosystems, and ecosystem dynamics are influenced, to varying degrees, by human activities" ([32], p. 6).

The interactions between human and the environment have become so complex that even the sustainable policies we design to mitigate eco-sociological threats can generate new unpredictable risks [116]. The social-cultural framework of explanation of risks overlooks its biophysical and planetary nature. Risk is not purely an anthropocentric concept, it is also today an "anthropocenic" (geo-anthropological) reality. As noticed by René Girard and Jean-Pierre Dupuy, traditional societies 
were based on an acceptation of the pure exteriority of fortune and hazards ([27], p. 126). Catastrophic events symbolized the wrath of Gods and materialized the action of incomprehensible external forces considered with awe and resignation. On the contrary, modern societies, are based on the idea that both their organization and their destination were purely mundane and humane. In a society assumed to be thoroughly human, biodiversity loss, pollution, nuclear proliferation has been frequently viewed as psycho-social constructs [117]. Such a "social-constructivist" perspective is not only misleading but also counterproductive to mitigate new global social-ecological threats: it is precisely because of their failure to recognize that human societies are dependent from non-human parameters-especially their bio-geological environment- that modern societies developed without taking into account their dependence to nature and the negative of effects of their development. In many ways, it is the same cognitive limitation, i.e., the incapacity to acknowledge both the non-human and objective component of risks affecting human societies and the naturalization of social interactions, which operates in the socio-cultural mode of explanation of risks.

Global environmental risks, like climate change, are not simply psycho-social constructs propagated to promote a new mode of social control on the individuals [118]; they are also the by-products of an economic mode of development where ecological deficits are shared by all, while the economic profits benefit a few [119] and that is currently transforming the Earth for centuries to come. Risks in the Anthropocene cannot be equated simply to the mathematical probability of an adverse event to happen in the near future. Risks are a concrete testimony of the difficulty to assess the multifactorial complexity of events already happening, resulting from a human mode of social-economic development, whose blindness to its dependence to nature has generated an unbalanced environment threatening human societies themselves.

Acknowledgments: The research leading to these results has received funding from the People Programme (Marie Curie Actions) of the European Union's Seventh Framework Programme (FP7/2007-2013) under REA grant agreement No. 269327 Acronym of the Project: EPSEI (2011-2015) entitled "Evaluating Policies for Sustainable Energy Investments: Towards an Integrated Approach on National and International Stage", within the results coordinated by gLAWcal-Global Law Initiatives for Sustainable Development and led by Professor Paolo Davide Farah.

Conflicts of Interest: The authors declare no conflict of interest.

\section{References}

1. Dodson, J. Introduction. In Changing Climates, Earth Systems and Society; Dodson, J., Ed.; Springer: New York, NY, USA, 2010; p. xix. ISBN 9048187176.

2. MEA. Living Beyond Our Means: Natural Assets and Human Well-Being (Statement from the MA Board of Directors); Island Press: Washington, DC, USA, 2005; p. 5. Available online: http:/ /www.millenniumassessment.org/ documents / document.429.aspx.pdf (accessed on 3 January 2017).

3. Kasperson, J.X.; Kasperson, R.E.; Dow, K. Global Environmental Risks and Society. In Global Environmental Risk; Kasperson, J.X., Kasperson, R.E., Eds.; United Nations University Press: London, UK, 2001; pp. 1-48. ISBN 92-808-1027-8 1.

4. Bostrom, N.; Cirkovic, M.N. Introduction. In Global Catastrophic Risks; Bostrom, N., Cirkovic, M.N., Eds.; Oxford University Press: Oxford, UK, 2011; p. 28. ISBN 9780199606504.

5. Serres, M. The Natural Contract; University of Michigan Press: Ann Arbor, MI, USA, 1995; p. 12. ISBN 0-472-09549-8.

6. Roger, A. Maitres et Protecteurs de la Nature: Contribution à la critique d'un prétendu 'contrat naturel'. In Maitres et Protecteurs de la Nature; Roger, A., Beaune, J.C., Eds.; Champ Vallon: Seyssel, France, 1991; p. 17. ISBN 2-87673-076-6.

7. Steffen, W.; Grinevald, J.; Crutzen, P.; McNeill, J. The Anthropocene: Conceptual and historical perspectives. Philos. Trans. R. Soc. A 2011, 369, 842-867. [CrossRef] [PubMed]

8. Latour, B. Agency at the time of the Anthropocene. New Lit. Hist. 2014, 45, 1-18. [CrossRef]

9. Berkess, F. Sacred Ecology; Taylor \& Francis: London, UK, 2012; ISBN 978-0415517324. 
10. Heurtebise, J.-Y.; Gaffric, G. L'écologie, Confucius et la démocratie: déconstruction de la rhétorique chinoise de 'civilisation écologique'. Ecol. Polit. 2013, 48, 51-61.

11. Crutzen, P.J. Geology of mankind. Nature 2002, 415, 23. [CrossRef] [PubMed]

12. Gibbard, P.L.; Walker, M.J.C. The term 'Anthropocene' in the context of formal geological classification. Geol. Soc. Lond. Spec. Publ. 2014, 395, 29-37. [CrossRef]

13. Hibbard, K.; Crutzen, P.; Lambin, E.; Liverman, D.M.; Mantua, N.J.; McNeill, J.R.; Messerli, B.; Steffen, W. Group Report: Decadal-Scale Interactions of Humans and the Environment. In Sustainability or Collapse? An Integrated History and Future of People on Earth; Constanza, R., Graumlich, L.J., Steffen, W., Eds.; MIT Press: Cambridge, MA, USA, 2007; pp. 341-377. ISBN 9780262251228.

14. Steffen, W. The trajectory of the Anthropocene: The Great Acceleration. Anthr. Rev. 2015, 2, 81-98. [CrossRef]

15. Rosenbaum, M.S.; McMillan, A.A.; Powel, J.H.; Cooper, A.H.; Culshaw, M.G.; Northmore, J.K. Classification of artificial (man-made) ground. Eng. Geol. 2003, 69, 399-409. [CrossRef]

16. Lewis, S.L.; Maslin, M.A. Defining the Anthropocene. Nature 2015, 519, 171-180. [CrossRef] [PubMed]

17. Zalasiewicz, J. Colonization of the Americas' 'Little Ice Age' climate, and bomb produced carbon: Their role in defining the Anthropocene. Anthr. Rev. 2015, 2, 117-127. [CrossRef]

18. Carey, J. Are we in the "Anthropocene"? Proc. Natl. Acad. Sci. USA 2016, 113, 3908-3909. [CrossRef] [PubMed]

19. Rockström, J.; Steffen, W.; Noone, K.; Persson, A.; Chapin, F.S.; Lambin, E.F.; Lenton, T.M.; Scheffer, M.; Folke, C.; Schellnhuber, H.J.; et al. A safe operating space for humanity. Nature 2009, 461, 472-475. [CrossRef] [PubMed]

20. Gaffney, O.; Steffen, W. The Anthropocene equation. Anthr. Rev. 2017, 4, 53-61. [CrossRef]

21. Ceballos, G.; Ehrlich, P.R.; Barnosky, A.D.; García, A.; Pringle, R.M.; Palmer, T.M. Accelerated modern human-induced species losses: Entering the sixth mass extinction. Sci. Adv. 2015, 1, e1400253. [CrossRef] [PubMed]

22. World Health Organization (WHO). Quantitative Risk Assessment of the Effects of Climate Change on Selected Causes of Death, 2030s and 2050s; World Health Organization: Geneva, Switzerland, 2014; ISBN 978924 1507691.

23. Rosa, E.A. The logical structure of the social amplification of risk framework (SARF): Metatheoretical foundations and policy implications. In The Social Amplification of Risk; Pidgeon, N., Kasperson, R.E., Slovic, P., Eds.; Cambridge University Press: Cambridge, MA, USA, 2003; pp. 47-79. ISBN 9780521520447.

24. Carpenter, S.R.; DeFries, R.; Dietz, T.; Mooney, H.A.; Polasky, S.; Reid, W.V.; Scholes, R.J. Millennium Ecosystem Assessment: Research Needs. Science 2006, 314, 257-258. [CrossRef] [PubMed]

25. Daskalov, G.M.; Grishin, A.N.; Rodionov, S.; Mihneva, V. Trophic cascades triggered by overfishing reveal possible mechanisms of ecosystem regime shifts. Proc. Natl. Acad. Sci. USA 2007, 104, 10518-10523. [CrossRef] [PubMed]

26. Schneider, S.H. Abrupt Non-Linear Climate Change, Irreversibility and Surprise. In The Benefits of Climate Policy: Improving Information for Policy Makers; OECD: Paris, France, 2004; ISBN 9264108319.

27. Dupuy, J.-P. The Mark of the Sacred; Stanford University Press: Stanford, CA, USA, 2013; p. 27. ISBN 9780804776899.

28. Griner, S. Living in a World Risk Society: A reply to Mikkel V. Rasmussen. Millenn. J. Int. Stud. 2002, 31, 149. [CrossRef]

29. World Commission on Environment and Development (WCED). Our Common Future; Oxford University Press: Oxford, UK, 1987; ISBN 019282080X.

30. Heurtebise, J.-Y. The Concept of Sustainability and its consequences for Energy Policies. In World Scientific Reference on Globalisation in Eurasia and the Pacific Rim, Volume 3 Energy; Farah, P., Rossi, P., Eds.; Imperial College Press: London, UK; World Scientific Publishing: Singapore, 2015; pp. 211-226. ISBN 978-981-4447-79-9.

31. Lee, L. Living within One's Own Ecological Means. Sustainability 2009, 1, 1412-1430. [CrossRef]

32. Chapin, F.S.; Folke, C.; Kofinas, G.P. Principles of Ecosystem Stewardship; Springer: London, UK, 2009; ISBN 13 978-0387730325.

33. Renn, O. White Paper on Risk Governance: Towards an integrative framework. In Global Risk Governance: Concept and Practice Using IRGC Framework; Renn, O., Walker, K.D., Eds.; Springer: Heidelberg, The Netherlands, 2008; pp. 3-73. ISBN 978-1-4020-6798-3. 
34. Slovic, P. Perception of risk: Reflections on the psychometric paradigm. In Social Theories of Risk; Krimsky, S., Golding, D., Eds.; Praeger: Westport, CT, USA, 1992; pp. 117-152. ISBN 13 978-1405153362.

35. Jasanoff, S. The songlines of risk. Environmental values. Risk 1999, 8, 135-152. [CrossRef]

36. Beck, U. From Industrial Society to the Risk Society: Questions of Survival, Social Structure and Ecological Enlightenment. Theory Cult. Soc. 1992, 9, 97-123. [CrossRef]

37. Alexander, J.C.; Smith, P. Social Science and Salvation: Risk Society as Mythical Discourse. Z. Sociol. 1996, 25, 251-262. [CrossRef]

38. Slater, D.; Ritzer, G. Ling in the Risk Society: Interview with Ulrich Beck. J. Consum. Cult. 2001, 1, $261-277$. [CrossRef]

39. Douglas, M. The depoliticisation of risk. In Culture Matters: Essays in Honor of Aaron Wildavsky; Ellis, R.J., Thompson, M., Eds.; Westview Press: Boulder, CO, USA, 1997; pp. 121-132. ISBN 13 978-0813331188.

40. Douglas, M. Purity and Danger: An Analysis of the Concepts of Pollution and Taboo; Routledge: New York, NY, USA, 1984; p. 117. ISBN 13 978-0415289955.

41. Beck, U. Risk Society: Towards a New Modernity; Sage: London, UK, 2000; p. 7. ISBN 9780803983465.

42. Douglas, M. Risk and Blame: Essays in Cultural Theory; Routledge: London, UK, 1992; p. 28. ISBN 10: 0415119995.

43. Douglas, M.; Wildavsky, A. Risk and Culture: An Essay on the Selection of Technological and Environmental Dangers; University of California Press: Berkeley, CA, USA, 1983; p. 184. ISBN 139780520050631.

44. Knight, F.H. Risk, Uncertainty, and Profit; Houghton Mifflin Company: Boston, NY, USA, 1921; p. 233. ISBN 9781614276395.

45. Aven, T. Misconceptions of Risk; John Wiley \& Sons: Chichester, NH, USA, 2010; p. 87. ISBN 13 978-0470683880.

46. Jamieson, D. Uncertainty and the Political Process. Ann. Am. Acad. Political Soc. Sci. 1996, 545, 35-43. [CrossRef]

47. Jobin, P.; Tseng, Y.-H. Guinea Pigs Go to Court: Epidemiology and Class Actions in Taiwan. In Powerless Science? The Making of the Toxic World in the Twentieth Century; Boudia, S., Jas, N., Eds.; Berghahn Books: New York, NY, USA; 2014; pp. 170-193. ISBN 978-1-78238-236-2.

48. Di Lucia, L.; Ahlgren, S.; Ericsson, K. The dilemma of indirect land-use changes in EU biofuelpolicy-An empirical study of policy-making in the context of scientific uncertainty. Environ. Sci. Policy 2012, 16, 9-19. [CrossRef]

49. Latour, B. Politics of Nature; Harvard University Press: Harvard, CA, USA, 2004; ISBN 9780674013476.

50. Jungermann, H.; Slovic, P. Charakteristika individueller Risikowahrnehmung. In Risiko ist ein Konstrukt. Wahrnehmungen zur Risikowahrnehmung; Bayerische, R., Ed.; Knesebeck: Munich, Germany, 1993; pp. 89-107. ISBN 9783926901606.

51. Saloojee, Y.; Dagli, E. Tobacco industry tactics for resisting public policy on health. Bull. World Health Organ. 2000, 78, 911-912. [CrossRef]

52. Gouritin, A. EU Environmental Law, International Environmental Law, and Human Rights Law: The Case of Environmental Responsibility; Brill: Leiden, The Netherlands, 2016; ISBN 900430214X, 9789004302143.

53. Polka, A.; Schmutzler, A. Lobbying against environmental regulation vs. lobbying for loopholes. Eur. J. Political Econ. 2005, 21, 915-931. [CrossRef]

54. Rakel, H. Scientists as Expert Advisors: Science Cultures vs. National Cultures? In Experts in Science and Society; Kurz-Milcke, E., Gigerenzer, G., Eds.; Kluwer: New York, NY, USA, 2004; pp. 3-26. ISBN 13 978-0306479038.

55. Chaney, R.L. Twenty years of land application research. BioCycle 1990, 31, 54-59. [CrossRef]

56. Robbins, P.; Hintz, J.; Moore, S.A. Environment and Society: A Critical Introduction; Wiley-Blackwell: Hoboken, NJ, USA, 2011; ISBN 13 978-1405187602.

57. Cable, S.; Shriver, T.E.; Tamara, L.M. Risk Society and Contested Illness: The Case of Nuclear Weapons Workers. Am. Sociol. Rev. 2008, 73, 380-401. [CrossRef]

58. Oxfam. An Economy for the 1\%-How Privilege and Power in the Economy Drive Extreme Inequality and How This Can Be Stopped; Oxfam GB: Oxford, UK, 2016; p. 2. ISBN 978-1-78077-993-5.

59. Assadourian, E. The Rise and Fall of Consumer Cultures. In State of the World 2010: Transforming Cultures; World Watch Institute, Ed.; W.W. Norton \& Company: New York, NY, USA, 2010; pp. 3-20. ISBN 13 978-0393337266.

60. Burkett, P. Marx and Nature. A Red and Green Perspective; Palgrave Macmillan: New York, NY, USA, 1999; p. 217. ISBN 13 978-1608463695. 
61. Heurtebise, J.-Y. Global Risks: Cause and consequence of the new interactions between science, technology and society. In The Handbook of Global Science, Technology and Innovation; Archibugi, D., Filippetti, A., Eds.; Wiley-Blackwell: Oxford, UK, 2015; pp. 558-574. ISBN 978-1-118-73906-8.

62. Funtowicz, S.; Ravetz, J.R. Science for the post-normal age. Futures 1993, 25, 735-755. [CrossRef]

63. Latour, B. An Inquiry into Modes of Existence; Harvard University Press: Harvard, CA, USA, 2013; ISBN 10 0674724992.

64. Funtowicz, S.; Strand, R. Models of science and policy. In Biosafety First: Holistic Approaches to Risk and Uncertainty in Genetic Engineering and Genetically Modified Organisms; Traavik, T., Ching, L.L., Eds.; Tapir Academic Press: Trondheim, Norway, 2003; pp. 263-278. ISBN 978-983-2729-98-3.

65. Heurtebise, J.Y.; Gaffric, G. L'écologie, Confucius et la démocratie : Déconstruction de la rhétorique chinoise de la civilisation écologique. Ecol. Politique 2013, 48, 51-61. [CrossRef]

66. Pan, J. China's Environmental Governing and Ecological Civilization; Springer: Berlin, Germany, 2015; ISBN 978-3-662-47428-0.

67. Miller, A.L. The CCP Central Committee's Leading Small Groups. China Leadership Monitor 2008, 26. Available online: http://www.hoover.org/research/ccp-central-committees-leading-small-groups (accessed on 28 July 2017).

68. Miller, A.L. More Already on the Central Committee's Leading Small Groups. China Leadership Monitor 2014, 44. Available online: http://www.hoover.org/research/more-already-central-committees-leading-smallgroups(accessed on 28 July 2017).

69. Pan, Y. The Rich Consume and the Poor Suffer the Pollution. China Dialogue, 27 October 2006. Available online: https: / www.chinadialogue.net/article/show/single/en/493--The-rich-consume-and-the-poorsuffer-the-pollution- (accessed on 3 January 2017).

70. Pan, Y. Evolution of an Ecological Civilization. Beijing Review, 9 November 2006. Available online: www. bjreview.com.cn/expert/txt/2006-12/15/content_50890.htm (accessed on 3 January 2017).

71. Tu, W. The Ecological Turn in New Confucian Humanism: Implications for China and the World. Daedalus 2001, 130, 243-264.

72. Wang, Y. Wang Yangming Quanji 2; Guji Chubanshe: Shanghai, China, 1992; ISBN 139787532512423.

73. De Bary, W.T.; Lufrano, R. Sources of Chinese Tradition; Columbia University Press: New York, NY, USA, 1960; pp. 659-660. ISBN 13 978-0231109390.

74. The institutional and cultural advantages of the edification of a Chinese Ecological Civilization. People's Daily, 5 March 2015, Volume 3. Available online: http:/ / paper.people.com.cn/rmrb/html/2015--03/05/nw. D110000renmrb_20150305_3--03.htm (accessed on 3 January 2017).

75. Tigao guojia wenhua ruan shili. People's Daily, 29 December 2007. Available online: http://news.xinhuanet. com/newscenter/2007--12/28/content_7327640.htm (accessed on 3 January 2017).

76. Nye, J.S. Bound to Lead: The Changing Nature of American Power; Basic Book: New York, NY, USA, 1990; ISBN 13 978-0465007448.

77. Nye, J.S. Can the United States really lead the World? He, X., Gai, Y., Eds.; Military Friendship and Culture Press: Beijing, China, 1992; ISBN 9787800271557.

78. Nye, J.S. China's Soft Power Deficit. Wall Street Journal, 9 May 2012. Available online: http:/ / www.wsj.com/ articles/SB10001424052702304451104577389923098678842 (accessed on 3 January 2017).

79. Hall, I.; Smith, F. The Struggle for Soft Power in Asia: Public Diplomacy and Regional Competition. Asian Secur. 2013, 9, 1-18. [CrossRef]

80. Courmont, B. Le soft power chinois: Entre stratégie d'influence et affirmation de puissance. Revue D'études Comparatives Est-Ouest 2012, 43, 287-309. [CrossRef]

81. Balme, S. L'impuissance Paradoxale du 'Soft Power' de la Chine Post-Mao. CERISCOPE Puissance, 2013. Available online: http:/ / ceriscope.sciences-po.fr/puissance/content/part4/l-impuissance-du-soft-powerchinois (accessed on 3 January 2017).

82. Zhao, X.F.; Li, X.; Cai, W.H. Review of China's Soft Power Research from the Perspective of Local Conversion. In Soft Power Innovation and Development in Today's China; Zhu, K.L., Zhang, H., Eds.; Aussino Academic Publishing House: Riverwood, CA, USA, 2011; pp. 38-43. ISBN 9781618396518.

83. Sakamoto, H. A New Possibility of Global Bioethics as an Intercultural Social Tuning Technology. In Cross-Cultural Perspectives on the (Im)Possibility of Global Bioethics; Tao Lai Po-wah, J., Ed.; Springer: London, UK, 2002; pp. 359-368. ISBN 978-94-017-1195-1. 
84. Zhang, Q.Z. Traditional Chinese Culture; Beijing Foreign Language Press: Beijing, China, 2009; p. 14. ISBN 978-7-04-028909-1.

85. Lu, S.Y. The Speech of the Lynx: Reflections on the literature of spiritual ecology; Social Science Academic Press: Beijing, China, 2001; ISBN 9787801494450.

86. Gaffric, G. Taïwan, Écriture et Écologie: Explorations Écocritiques Autour des Oeuvres de Wu Ming-Yi. Ph.D. Thesis, Université Lyon III-Jean Moulin, Lyon, France, March 2014.

87. Slovic, S. Landmarks in Chinese Ecocriticism and Environmental Literature: The Emergence of a New Ecological Civilization; Social Sciences in China Press: Beijing, China, 26 October 2012. Available online: http:/ / www. csstoday.net/ywpd/Topics/28706.html (accessed on 3 January 2017).

88. Weller, R.P. Discovering Nature: Globalization and Environment Culture in China and Taiwan; Cambridge University Press: Cambridge, MA, USA, 2006; p. 4. ISBN 13 978-0-521-83959-4.

89. Zhuang, Z. The Complete Works of Zhuangzi; Burton, W., Ed.; Columbia University Press: New York, NY, USA, 2013; ISBN 9780231164740.

90. Dallmayr, F. Return to Nature? An Ecological Counterhistory; The University Press of Kentucky: Lexington, KY, USA, 2011; p. 33. ISBN 100813166349.

91. Ulanowicz, R.E. Life after Newton: An Ecological Metaphysic. In The Philosophy of Ecology. From Science to Synthesis; Keller, D.R., Golley, F.B., Eds.; University of Georgia Press: Athens, GA, USA, 2000; pp. 81-100.

92. White, L. The Historical Roots of Our Ecologic Crisis. Science 1967, 155, 1203-1207. [CrossRef] [PubMed]

93. LeVasseur, T.; Peterson, A. Religion and Ecological Crisis. The "Lynn White Thesis" at Fifty; Routledge: New York, NY, USA, 2017; ISBN 13 978-1138644120.

94. Nash, J. Loving Nature: Ecological Integrity and Christian Responsibility; Abingdon Press: Nashville, TN, USA, 1991; ISBN 0687228247.

95. Marx, K.; Engels, F. Manifesto of the Communist Party; International Publishers: New York, NY, USA, 1975; pp. 482-483. ISBN 13 978-0717802418.

96. Elvin, M. The Retreat of the Elephants: An Environmental History of China; Yale University Press: New Haven, CT, USA, 2004; ISBN 13 978-0300119930.

97. Shapiro, J. Mao's War against Nature: Politics and the Environment in Revolutionary China; Cambridge University Press: Cambridge, UK, 2001; pp. 9-10. ISBN 139780521781503.

98. Han, S.-J. Asian Values: An Asset or a Liability. In Changing Values in Asia: Their Impact on Governance and. Development; Han, S.-J., Ed.; Japan Center for International Exchange: Tokyo, Japan, 2003; pp. 3-9. ISBN 981-230-063-5.

99. Yan, S. Masking the pollution. Global Times, 12 October 2011. Available online: http:/ /www.globaltimes.cn/ content/678904.shtml (accessed on 3 January 2017).

100. Heise, U.K. Sense of Place and Sense of Planet: The Environmental Imagination of the Global; Oxford University Press: Oxford, UK, 2008; ISBN 13 978-0195335644.

101. Yearley, S. The Green Case: A Sociology of Environmental Issues, Arguments and Politics; Routledge: London, UK, 1991; p. 45. ISBN 13 978-0415083812.

102. Mayer, S. Literature in the Anthropocene: World Risk Society and Ecoglobalism. In Handbook of Ecocriticism and Cultural Ecology; Zapf, H., Ed.; Walter de Gruyter GmbH: Berlin, Germany, 2016; pp. 494-510. ISBN 978-3-11-031459-5.

103. Delanty, G.; Mota, A. Governing the anthropocene: Agency, governance, knowledge. Eur. J. Soc. Theory 2017, 20, 9-38. [CrossRef]

104. Zhang, W.; Li, H.L.; An, X.B. Ecological Civilization Construction is the Fundamental Way to Develop Low-carbon Economy. Energy Procedia 2011, 5, 839-843. [CrossRef]

105. Morrison, R. Ecological Democracy; South End Press: Boston, MA, USA, 1995; p. 12. ISBN 13 978-0896085138.

106. Ophuls, W. Ecology and the Politics of Scarcity; W.H. Freeman and Company: San Francisco, CA, USA, 1977; p. 150. ISBN 13 978-0716704812.

107. Eckersley, R. The Green State: Rethinking Democracy and Sovereignty; MIT Press: Cambridge, MA, USA, 2004; ISBN 13 978-0262550567.

108. Heurtebise, J.-Y. Understanding Non-Trade Concerns through Comparative Chinese and European Philosophy of Law. In China's Influence on Non-Trade Concerns in International Economic Law; Farah, P.D., Cima, E., Eds.; Routledge Publishing: London, UK, 2016; pp. 285-292.

109. Sakamoto, H. Foundations of East Asian Bioethics. Eubios J. Asian Int. Bioeth. 1996, 6, 31-32. [CrossRef] 
110. UN General Assembly, International Covenant on Economic, Social and Cultural Rights, United Nations, Treaty Series. 16 December 1966, Volume 993, p. 3. Available online: http://www.refworld.org/docid/ 3ae6b36c0.html (accessed on 3 January 2017).

111. Shue, H. Basic Rights: Subsistence, Affluence, and U.S. Foreign Policy; Princeton University Press: Princeton, NJ, USA, 1980; p. 23. ISBN 13 978-069102929.

112. United Nations. Report of the United Nations Conference on the Human Environment (Stockholm Conference); United Nations Document A/CONF.48/14/Rev.1; United Nations Publications: New York, NY, USA, June 1972. Available online: http:/ / www.un-documents.net/aconf48-14r1.pdf (accessed on 28 July 2017).

113. United Nations Economic Commission for Europe (UNECE). Convention on Access to Information, Public Participation in Decision-making and Access to Justice in Environmental Matters (Aarhus Conference); The Stationery Office (TSO): Norwich, UK, 2005; UN Doc. ECE/CEP/43, 38 I.L.M. 517; 25 June 1998. Available online: http:/ / www.unece.org/fileadmin/DAM/env/pp/documents/cep43e.pdf (accessed on 28 July 2017).

114. Descola, P. Par-delà Nature et Culture; Gallimard: Paris, France, 2006; ISBN 13 978-2070465873.

115. Latour, B. We Have Never Been Modern; Harvard University Press: Harvard, MA, USA, 1993 ; p. 31. ISBN 978-0-674-94839-6.

116. Holling, C.S. Resilience and Stability of Ecological Systems. Ann. Rev. Ecol. Sys. 1973, 4, 1-23. [CrossRef]

117. Yearly, S. The Social Construction of Environmental Problems: A Theoretical Review and Some Not-Very-Herculean Labors. In Sociological Theory and the Environment. Classical Foundations, Contemporary Insights; Dunlap, R.E., Buttel, F.H., Dickens, P., Gijswijt, A., Eds.; Rowman \& Littlefield Publishers: Oxford, UK, 2002; pp. 274-285. ISBN 13 978-0742501867.

118. Luke, T.W. On Environmentality: Geopower and Ecoknowledge, in the Discourses of Contemporary Environmentality. Cult. Criti. 1995, 31, 57-82. [CrossRef]

119. Eyles, J.; Baxter, J. Environments, Risks and Health: Social Perspectives; Routledge: London, UK, 2016 ; p. 156. ISBN 9780444522726.

(C) 2017 by the author. Licensee MDPI, Basel, Switzerland. This article is an open access article distributed under the terms and conditions of the Creative Commons Attribution (CC BY) license (http://creativecommons.org/licenses/by/4.0/). 